\title{
KEBEBASAN BERAGAMA DAN RANAH TOLERANSINYA
}

\author{
Siti Faridah \\ Mahasiswa Fakultas Hukum, Universitas Negeri Semarang \\ Surel: sfaridah99@gmail.com
}

\begin{abstract}
ABSTRAK
Pembentukan hukum tidak lepas dari putusan-putusan hakim (judge made law) yang terkait dengan penegakan hukum, sedangkan penegakan hukum pada hakikatnya adalah merupakan suatu proses untuk mewujudkan tujuan-tujuan hukum ide-ide hukum menjadi kenyataan. Tulisan ini mengkaji tentang aspek-aspek hak asasi manusia dalam negara hukum, antara hukum progresif dan hukum positif. Hukum Progresif adalah hukum pro keadilan dan pro rakyat, artinya dalam

berhukum para pelaku hukum dituntut mengedepankan kejujuran, empati, kepedulian kepada rakyat dan ketulusan dalam penegakan hukum.
\end{abstract}

RIWAYAT ARTIKEL

Article History

Diterima 22 Oktober 2018

Dipublikasi 20 November 2018

\section{KATA KUNCI}

Keywords

Beragama, HAM, Kebebasan, dan Warga Negara
HOW TO CITE (saran perujukan):

Faridah, Siti (2018). "Kebebasan Beragama Dan Ranah Toleransinya", Lex Scientia Law Review. Volume 2 No. 2, November, hlm. 199 -214

\section{PENDAHULUAN}

HAM yang di Indonesia dikenal dengan sebutan dari Hak Asasi Manusia dalam bahasa Belanda sendiri merupakan terjemahan dari "grondrechten". Tidak sedikit orang menyebutnya dengan istilah hak-hak fundamental. Sebenarnya, pengertian HAM merupakan alih bahasa dari bahasa Perancis yaitu "droits de l'homme", adapun rangkaian lengkapnya berbunyi "Declaration des droits de l'homme et du Citoyen", yaitu mengenai pernyataan Hak Asasi Manusia (HAM) warga negara Perancis yang memproklamirkan kemerdekaannya di tahun 1789 sebagai pencerminan keberhasilan revolusi warganegaranya yang bebas dari kekangan penguasa tunggal pada saat itu. Freedom of Religion or Belief (FORB) selalu memiliki daya tarik lebih untuk dibahas, mengingat isu agama dan sosial politik berkembang secara dinamis di masyarakat. Selain itu, isu agama yang bersifat sensitive dan 
emosional selalu menarik untuk dikaji lebih dalam karena ada saja gesekan-gesekan yang terjadi juga tidak lepas hubungannya dengan persoalan Hak Asasi Manusia (HAM).

(Asshiddiqie, 2007: 615) Prinsip dari HAM adalah hak yang melekat pada diri setiap manusia yang harus di lindungi. Sehingga, hak asasi manusia selalu menjadi materi inti dalam Undang-Undang Dasar Negara Modern. Dalam hal ini termasuk pula dalam materi Undang-Undang Dasar Negara Republik Indonesi Tahun 1945 pasca amandemen. Dalam konteks kebebasan beragama, prinsip demokrasi merupakan sebuah konsep politik ideal karena dibangun di atas kesadaran manusia sebagai makhluk yang memiliki kebebasan berkehendak. Demokrasi seringkali diartikan sebagai kebebasan untuk mengemukakan pendapat sehingga pembatasan agama dianggap bertentangan dengan prinsip demokrasi itu sendiri.

Karena itulah gagasan dari kalangan liberalis menghendaki tidak ada pembatasan dalam meyakini suatu keyakinan atau agama tertentu termasuk jika tidak meyakini adanya Tuhan. Mengenai hal-hal yang bersifat intern, terdapat batasan batasan tersendiri untuk seseorang dapat ikut campur atau tidak. Jika demokrasi diartikan sebagai sebuah kebebasan untuk berekspresi dan mengeluarkan pendapat, mestinya setiap warga negara bebas untuk berekspresi sesuai dengan keyakinan atau agama yang dianutnya. Namun, tidak bisa dibayangkan betapa kacaunya sebuah negara seandainya tidak ada norma yang bisa dijadikan sebagai aturan untuk mengatur setiap warga negara dalam mengekspresikan kebebasan beragama. (Hafsin, 2010: 10)

(Johanis, 2014: 7) Setiap manusia memiliki hak untuk berpikir secara bebas, mendengar, melihat, mengeluarkan pendapat, mengungkapkan ide dan memeluk salah satu agama. Apabila kebebasan beragama dijamin dan dilindungi oleh hukum dan HAM, maka konsekuensinya kebebasan beragama tersebut adalah kebebasan bagi semua orang untuk beragama, dan berdampak pada perbedaan pandangan antara satu agama dengan agama yang lain, khususnya yang berkaitan dengan teologis dan dogmatis, misalnya tentang keselamatan dan pembenaran. Mempertemukan dan menjembatani perbedaan di antara agama-agama serta antar umat beragama merupakan suatu hal yang sulit dan sensitif, manakala tidak ditempuh dengan upaya yang saling menghargai, toleran, dan persuasive.

Dalam realitasnya, sebagian negara-negara muslim modern bukan saja telah menerapkan konstitusi yang memberikan jaminan hak-hak sipil dan memperlakukan secara sama warga negara di depan hukum, bahkan mereka telah meratifikasi ICCPR (International Covenant on Civil and Political Rights) yang menyatakan bahwa hak untuk memeluk agama diberikan kepada warga negara dan dijamin secara kuat di dalamnya. (Sayogie, 2013: 43) 
(Wignjosoebroto: 1996)Hak Asasi Manusia (HAM) merupakan hak-hak melekat secara kodrati pada setiap mahluk yang bersosok biologis sebagai manusia yang memberikan jaminan moral dan legal kepada setiap manusia itu untuk menikmati kebebasan dari setiap bentuk penghambaan, penindasan, perampasan, penganiayaan atau perlakuan apapun lainya yang menyebabkan manusia itu tidak dapat hidup secara layak sebagai manusia yang dimuliakan Allah. Kebebasan beragama dan berkeyakinan bukan hanya menjadi urusan negara atau NGO yang bergerak dalam advokasi HAM dan kebebasan beragama. Akan tetapi merupakan tanggung jawab dari semua umat beragama, baik secara internal maupun eksternal dengan para penganut agama-agama lain. Sehingga, kebebasan beragama menjadi tanggung jawab semua pihak. (Yusdani, 2011: 268-269)

(Rhona K. M. Smith dkk, 2008: 3) Jhon Locke menjelaskan bahwa semua individu mempunyai hak yang melekat atas hidup, kebebasan dan kepemilikan yang merupakan miliki mereka sendiri dan tidak dicabut atau dipereteli oleh negara. (Fatmawati, 2011: 499) Negara Indonesia merupakan negara yang memberikan jaminan terhadap hak atas kebebasan beragama dan beribadah sebagaimana diatur dalam Pasal 29 UUD 1945. (Adji, 1985: 37-38) mengemukakan bahwa salah satu ciri Negara Hukum Indonesia adalah tidak adanya pemisahan yang rigid dan mutlak antara agama dan negara, karena agama dan negara berada dalam hubungan yang harmonis. Sementara (Azhary, 1992: 74) mengemukakan bahwa salah satu ciri Negara Hukum Indonesia adalah hubungan yang erat antara agama dengan negara yang bertumpu pada Ketuhanan Yang Maha Esa, dan dalam Negara Hukum Pancasila tidak boleh terjadi pemisahan antara agama dan baik secara mutlak maupun tidak, karena hal itu akan bertentangan dengan Pancasila dan UUD 1945.

\section{Metode Penulisan}

Penelitian ini merupakan penelitian hukum normatif atau penelitian hukum kepustakaan yang mengandalkan beberapa bahan hukum seperti bahan primer, bahan sekunder, dan bahan hukum tersier, sebagai berikut:

1. Bahan hukum primer, yakni bahan hukum yang diperoleh dari sejumlah peraturan perundang-undangan, seperti dalam Undang-Undang Dasar Negara Republik Indonesia tahun 1945, DUHAM, dan Undang-Undang No. 39 Tahun 1999 tentang HAM.

2. Bahan hukum sekunder, yakni bahan hukum yang dapat menunjang pemahaman terhadap bahan hukum primer, yang diperoleh dari literatur yang relevan.

3. Bahan hukum tersier, yakni bahan hukum yang dapat menerangkan bahan hukum primer dan bahan hukum sekunder, yang diperoleh dari kamus atau ensiklopedia.

Data yang diperoleh dari berbagai bahan hukum tersebut diatas selanjutnya dianalisis dengan pendekatan perbandingan (comparative approach). 


\section{PEMBAHASAN}

\section{A. Esensi dalam Beragama}

Agama menurut KBBI merupakan ajaran atau sistem yang mengatur tata cara keimanan (kepercayaan) dan peribadatan kepada Tuhan Yang Mahakuasa serta tata kaidah yang berhubungan dengan pergaulan manusia dengan manusia serta manusia dengan lingkungannya. Sedangkan Oxford Student dictionary mendefinisikan bahwa agama adalah suatu kepercayaan akan keberadaan suatu kekuatan pengatur supranatural yang menciptakan dan mengendalikan alam semesta. Disamping itu, Agama menurut Émile Durkheim adalah suatu sistem yang terpadu yang terdiri atas kepercayaan dan praktik yang berhubungan dengan hal yang suci dan menyatukan semua penganutnya dalam suatu komunitas moral yang di namakan umat.

(Khurotin, 2010: 43) Beragama merupakan sebuah prinsip seseorang yang dalam realitas nyata diaplikasikan dengan mempercayai suatu hal atau zat yang gaib dan kepercayaan tersebut terbentuk dalam ruang pribadi. Beragama bermakna mempercayai suatu agama. Sedangkan agama yang ada di dunia tidaklah sedikit. Realitas kehidupan sosial menjadi mungkin untuk mengakomodasi perbedaan dan keragaman di antara manusia. Problematika baru yang terjadi saat ini yaitu dimulai dengan realita bahwa konflik agama dipandang sebagai suatu fenomena yang nyata.

Karena hal tersebut umat beragama harus menemukan titik persamaan, bukan mencari perbedaan yang pada akhirnya justru akan berujung pada konflik sosial. Inti masalah sesungguhnya bahwa perselisihan atau konflik yang terjadi antar umat beragama terletak pada ketidakpercayaan yang ada dan saling mencurigai. Setiap individu yang berbudi luhur dapat ditunjukan dengan memiliki prinsip bahwa dalam beragama seharusnya mampu untuk mengendalikan diri dari emosi yang bisa memicu permusuhan. Setiap manusia seharusnya mau menanggalkan sikap egois, ingin menang sendiri dan menganggap dirinyalah yang selalu benar dalam hal yang berkaitan dengan agama.

(Rasjidi, 1990:26-33) Tidak sedikit pemuka agama yang mengatakan bahwa semua agama sama. Salah satunya adalah Paul F. Knitter, seperti yang dikutip dari (Rachman,1995: 28) ia mengatakan: "Anda tidak dapat mengatakan bahwa agama yang satu lebih baik dari yang lain. Semua agama, pada dasarnya, adalah relative yaitu terbatas, parsial, tidak lengkap sebagai jalan dalam melihat segala sesuatu. (Gavin dan Phenomenology, 2013: 87) Menganggap bahwa sebuah agama secara intrinsik lebih baik dari yang lain, sekarang, dirasakan oleh ahli agama sebagai sebuah sikap yang agak salah, ofensif, dan merupakan pandangan yang sempit". Setiap agama mengekspresikan bagian penting dari sebuah kebenaran. Universalisme beranggapan bahwa pada dasarnya semua agama adalah satu dan 
sama. Hanya saja, karena faktor historis-antropologis, agama lalu tampil dalam format yang plural. (Dormort, 2012: 19)

Pemikiran dan anggapan yang muncul mengenai penyamarataan atau generalisasi sebuah agama sering kali kita dengar dalam perbincangan masyarakat Indonesia terutama sebagai bentuk atau upaya toleransi antar umat beragama yang menjadi program penting pemerintah pada era Orde Baru. Melalui berbagai jenjang pendidikan diajarkan untuk memiliki sikap yang mampu menerima dan mempercayai bahwa agama yang ada di Indonesia sangatlah banyak (plural) sehingga perbedaan dalam agama atau keyakinan tidak lagi dipermasalahkan. Perbincangan yang terjadi mengenai agama (diskusi lintas agama) dianggap seakan-akan tabu dan harus dihindari karena dipandang akan merusak hubungan antar umat beragama dalam keutuhan bangsa.

Namun disisi lain, diskusi lintas agama diasumsikan mampu untuk merubah pandangan seorang penganut agama untuk bersikap toleran dan menghormati pemeluk agama lain. Namun faktanya, metode seperti ini tidak memberikan efek signifikan. Toleransi yang tumbuh dalam masyarakat hanyalah sesuatu yang bersifat semu belaka atau dapat dikatakan sebagai obsesi terhadap stabilitas yang ada tanpa memerhatikan bom waktu yang bila disimpan semakin lama justru akan meledak. Contohnya adalah adanya berbagai kasus seperti kasus Ambon, kasus Poso yang melibatkan sentimen keagamaan dan kasus-kasus lainnya yang selama ini terpendam atau bahkan tidak muncul ke permukaan.

(Permana, 2000: 14) Banyak sekali definisi yang dikeluarkan oleh para pakar tentang agama. Dengan sebegitu banyaknya definisi mengenai agama sehingga justru mengaburkan makna apa yang sebenarnya hendak kita pahami dari sebuah agama. Hal ini terjadi karena begitu sulitnya mendefinisikan terminologi yang bernama agama. Dalam sebuah tulisannya, Mukti Ali pernah menyatakan: "Barangkali tidak ada kata yang paling sulit diberi pengertian dan definisi selain dari kata agama". Agama sulit untuk didefinisikan disebabkan oleh hal yaitu:

(1) Pengalaman agama merupakan sesuatu yang berkaitan dengan batin seseorang (subjektif) dan sangat individualis atau bermakna privat.

(2) Pembahasan mengenai agama selalu melibatkan emosi yang kuat karena berkaitan dengan kepercayaan seseorang.

(3) Konsepsi seseorang tentang agama yang berbeda-beda.

E.B. Taylor mendefinisikan agama sebagai the faith in Spritual Beings (kepercayaan terhadap wujud spiritual). (Permana, 2000: 15)Sedangkan, Pratt mengemukakan bahwa agama ialah the serious and social attitude of individuals or communities toward the power or powers which they conceive as having ultimate control over their interests and destinies (sikap yang serius dan sosial dari individu-individu atau komunitas-komunitas kepada satu atau lebih kekuatan yang mereka anggap memiliki kekuasaan tertinggi terhadap kepentingan dan nasib mereka). Sementara itu, Everyman's Encyclopaedia, seperti dikutip Anshari, memaknai bahwa agama 
sebagai acceptance of obligation toward powerr higher than man himself (penerimaan atas tata aturan daripada kekuatan-kekuatan yang lebih tinggi daripada manusia itu sendiri). Selanjutnya, (Nasution, 1985: 10) menyajikan beberapa definisi agama, antara lain, sebagai berikut:

(1) Pengakuan terhadap adanya hubungan manusia dengan kekuatan gaib yang harus dipatuhi

(2) Mengikatkan diri pada suatu bentuk hidup yang mengandung pengakuan pada suatu sumber yang berada di luar diri manusia dan yang mempengaruhi perbuatanperbuatan manusia.

(3) Kepercayaan pada suatu kekuatan gaib yang menimbulkan cara hidup tertentu.

(4) Pengakuan terhadap adanya kewajiban-kewajiban yang diyakini bersumber pada suatu kekuatan gaib.

(5) Pemujaan terhadap kekuatan gaib yang timbul dari perasaan lemah dan perasaan takut terhadap kekuatan misterius yang terdapat dalam alam sekitar manusia.

Berdasar pada definisi yang ada diatas, dapat disimpulkan bahwa agama bukan merupakan suatu wujud yang berdiri sendiri, melainkan sesuatu yang melekat dan menyatu pada wujud lain, yaitu pada diri manusia yang beragama.

Di lihat dari segi bahasa, Rangkuti menegaskan bahwa kata ini berasal dari bahasa Sanskerta, A-gama (dengan a panjang). A berarti cara (the way), dan gama berarti to go, yaitu berjalan atau pergi. Berpangkal dari pengertian tsb, dapat ditegaskan bahwa agama berarti cara-cara berjalan untuk sampai kepada keridhaan Tuhan. Pengertian ini sejalan dengan makna kata Arab syari'ah, yang secara harfiah berarti jalan menuju sumber mata air. Kata syariah dipakai dalam pengertian jalan menuju sumber kehidupan atau jalan hidup (way of life). Secara definitif, agama adalah ajaran, petunjuk, perintah, larangan, hukum, dan peraturan, yang diyakini oleh penganutnya berasal dari dzat gaib Yang Maha Kuasa, yang dipakai manusia sebagai pedoman tindakan dan tingkah laku dalam menjalani hidup sehari-hari. Dengan kata lain, inti dari suatu agama ialah ajaran yang dipakai manusia sebagai pedoman hidup. Agama adalah ajaran dan berbagai aturan yang menjadi pedoman hidup yang terdiri atas pedoman dalam berfikir, pedoman dalam memandang dan menilai sesuatu, dan pedoman dalam bertindak sehari-hari. Setiap penganut agama yakin bahwa agama yang dianutnya bukanlah ciptaan manusia, tetapi sesuatu yang berasal dari Tuhan, kekuatan gaib yang memiliki kekuasaan melebihi kekuasaan yang dimiliki manusia. Tidak ada satupun penganut agama yang mau mengakui bahwa agamanya adalah produk budaya (dalam ilmu agama sering disebut agama ardhi). Bagi setiap penganutnya, agama mereka adalah agama samawi, yaitu agama yang berasal dari Yang Maha Tinggi. 
Agama sebagai pedoman hidup yang berasal dari kekuatan gaib, tentu saja tidak mungkin ada yang sama. Pernyataan yang mengatakan bahwa semua agama sama adalah suatu kebodohan dan pembodohan. Pendapat seperti itu tidak ubahnya bagaikan pernyataan bahwa semua binatang sama, yaitu sama-sama hewan atau menyatakan bahwa anjing sama dengan kucing, yaitu sama-sama memiliki bulu. Jika dianalogikan, dapatkah berdagang disamakan dengan merampok atau maling karena sama-sama bertujuan untuk mengumpulkan harta? Masing-masing agama, jelas punya ajaran dan ketentuan yang berbeda antara agama satu dengan yang lainnya. Dengan demikian, dapat ditegaskan bahwa naif bila dikatakan bahwa semua agama adalah sama dan yang membedakan hanya pada faktor historis dan sosiologisnya bukan pada hakikat dan isinya, sebagaimana dikatakan Radhakrisnan, seorang Universalis dari India (Rasjidi, 1990: 33). Pandangan seperti ini dapat dikatakan sebagai pandangan yang sesat dan menyesatkan. Dengan mengeneralisir agama maka yang terjadi adalah agama akan kehilangan nilai-nilai luhurnya karena manusia sebagai makhluk yang diberi kemampuan berfikir justru akan memilih agama yang paling mudah dan longgar dalam setiap aturannya. Agama sebagai pedoman hidup, jelas merupakan "beban" dan "ikatan" yang membebani dan membatasi sikap dan tindakan penganutnya. Sangat manusiawi jika seseorang memilih beban yang paling ringan dan ikatan yang paling longgar bila alternatif pilihan dinyatakan sama. Sikap toleran dalam beragama tidak perlu dibentuk dengan menyatakan bahwa semua agama sama karena kenyataannya masing-masing agama memang berbeda.

Salah satu faktor pendorong timbulnya anggapan bahwa semua agama sama adalah kebutuhan untuk menciptakan kehidupan yang damai dalam masyarakat majemuk seperti Indonesia. Melihat dari pengalaman sejarah orde baru, mengajarkan bahwa perbedaan agama serta kepercayaan yang terjadi di Indonesia sering menimbulkan hubungan yang tidak harmonis antara warga dalam suatu kelompok masyarakat. Bahkan, agama menjadi penyulut dalam konflik dan peperangan. Oleh karena itu, pembinaan sikap toleran di antara umat beragama memang sangat diperlukan. Hanya saja, pendekatan dan strategi yang digunakan perlu dikaji dengan seksama agar tidak kontra produktif. Sehingga tidak ada lagi konflik yang terjadi berlatar belakang agama. Sebab penganut agama yang baik seharusnya tidak bertentangan dengan sikap toleran.

\section{B. Kebebasan Beragama di Indonesia}

Pembangunan agama merupakan upaya mewujudkan agenda dalam meningkatkan kesejahteraan rakyat melalui peningkatan kualitas pelayanan dan pemahaman agama serta kehidupan beragama. Selain itu, pembangunan agama juga mencakup dimensi peningkatan kerukunan hidup umat beragama, yang mendukung peningkatan saling percaya dan harmonisasi antar kelompok masyarakat. 
Terminologi yang digunakan oleh Pemerintah secara resmi, konsep kerukunan hidup beragama mencakup 3 kerukunan yaitu: kerukunan intern umat beragama, kerukunan antar umat yang berbeda-beda agama, dan kerukunan antara (pemuka) umat beragama dengan Pemerintah. Tiga kerukunan tersebut biasa disebut dengan istilah "Tri Kerukunan Umat Beragama". Sedangkan toleransi beragama di Indonesia tak lepas dari bangsa Indonesia itu sendiri. Proselitisme sangat bertentangan dengan jiwa kemanusiaan yang memiliki kebebasan dalam berkehendak. Sebab, proselitisme merupakan usaha yang dilakukan oleh pihak luar untuk menarik seseorang untuk masuk pada agama atau kelompok tertentu. Maka dari itu, telah disepakati bersama bahwa hal tersebut merupakan suatu bentuk paksaan. Perpindahan agama yang dilakukan dengan kesadaran atau keinginan sendiri berdasarkan desakan rohaninya adalah hak pribadi seorang yang tidak dicampuri oleh orang lain sepanjang tidak terjadi pemaksaan, bujukan dan hal lain yang semacamnya. Hal itulah yang patut dihormati dan inilah yang diatur dalam Undang-undang Dasar 1945. (Darajad, dkk, 1996: 149-150)

1. Landasan ideologi Pancasila terdapat pada sila pertama disebutkan bahwa Ketuhanan Yang Maha Esa, ini berarti bahwa Pancasila sebagai falsafah negara menjamin dan sekaligus mencerminkan nilainilai luiur bangsa Indonesia yang hidup bersama kepercayaan kepada Tuhan Yang Maha Esa.

2. Landasan Konstitusi

- Negara berdasarkan kepada Tuhan Yang Maha Esa

- Negara menjamin tiap penduduk untuk memeluk agamanya masing-masing dan beribadat menurut agamanya dan kepercayaan itu

3. Landsan Operasional Berupa Ketetapan MPR

4. Adapun ketetapan yaitu TAP MPR No. II/MPR/1976 Tentang P4 tentang sila Ketuhanan Yang Maha Esa menyebutkan:

- Percaya dan taqwa kepada Tuhan Yang Maha Esa sesuai dengan kepercayaan yang masingmasing menurut dasar kemanusiaan yang adil dan beradap

- Hormat menghormati bekerja sama antar pemeluk yang berbeda-beda sehingga

- Saling menghormati, bekerja sama antar pemeluk agama dan penganut kepercayaan yang berbedabeda sehingga hidup rukun

- Saling menghormati kebebasan menjalankan ibadah sesuai dengan agama dan kepercayaannya

- Tidak memaksakan sesuatu agama dan kepecayaan keppada orang lain (Suripto, BA, dkk, 1993: 86)

Seiring dengan arti pentingnya agama dalam kehidupan berbangsa, maka kehidupan beragama mendapat tempat khusus dalam masyarakat berdasarkan Pancasila. Pembinaan kehidupan beragama senantiasa diupayakan oleh pemerintah baik yang meliputi aspek pembinaan kesadaran beragama, kerukunan dan toleransi, kreativitas dan aktivitas keagamaan serta pembinaan sarana dan fasilitas keagamaan. (Hatta, 1981: 14) 


\section{Kenapa Kita Bisa Intolerant?}

Kerukunan hidup antar umat beragama tidak mungkin lahir dari sikap fanatisme buta dan sikap tidak peduli atas hak keberagamaan dan perasaan orang lain. Tetapi hal ini bukan berarti bahwa kerukunan hidup umat beragama didasarkan pada sikap sinkretis atau mencari penyesuaian antara dua aliran agama, sebab hal ini justru akan menimbulkan kekacauan dan merusak nilai agama itu sendiri. Sebab agama bukan merupakan sebuah kebudayaan yang bisa di asimilasi. Kekacauan yang terjadi pada komunitas keagamaan muncul diakibatkan kurangnya kesadaran beragama sehingga menyebabkan banyak terjadi konflik antar umat beragama. Sikap etnosentris yang mucul terhadap agamanya, sehingga memandang agama orang lain adalah agama yang salah, dan agamanya adalah agama yang paling benar. Segala hal yang berkaitan dengan agama dan kepercayaan akan selalu menjadi bahan yang sensitif untuk dikaji. Bila setiap agama saling keras dan egois bahwasannya memandang agamanya lah yang paling benar dan agama lain salah, maka hal ini akan menimbulkan kekacauan dan lebih parahnya lagi memicu konflik antar umat beragama. Sikap yang etnosentris seperti ini tidak dibenarkan. Sebab akan sangat mudah menyulut permasalahan dengan api yang berkedok agama. Karena untuk memastikan sebuah agama yang paling benar bukanlah suatu hal yang naif sebab untuk mengetahui mana agama yang murni merupakan hal yang sangat sulit dan bahkan tidak mungkin dapat diketahui, mengingat agama itu hadir dalam realitas kehidupan yang berkembang atau dengan istilah lain berevolusi sesuai dengan perkembangan manusia. Maka dari itu, agama tidak dapat dilepaskan kaitannya dengan sejarah. Namun, sejarah selalu memiliki kelemahan dalam memorinya yang disebabkan karena memori manusia yang sangat terbatas dan sulit untuk mengingat hal-hal secara detail dan berurut.

Masyarakat bergerak dinamis sesuai dengan perkembangan jaman. Dalam masyarakat sederhana atau primitif, manusia memiliki karakteristik yang serba homogen baik dalam budaya, agama maupun struktur sosial. Agama yang dipahami oleh masyarakat seperti ini adalah agama yang dekat dengan simbolsimbol. Simbol-simbol ini memiliki peran dominan terhadap keberagamaan mereka. Kebanyakan dari masyarakat sederhana ini berpendidikan rendah atau dalam lingkup "ordinary people". Mereka memahami agama orang lain dengan perasaan antipati. Toleransi yang dikembangkan dalam masyarakat ini tidak terjalin atau berjalan abnormal. Mereka mudah tersentuh atau tersinggung bila ajaran keyakinan atau agama mereka sepertinya dihina oleh pemeluk agama lain. Mereka merespon langsung dengan mempertahankan taruhan jiwa. 
Masyarakat kompleks atau masyarakat multikultural tersusun dari keanekaragaman budaya, masyarakat dan struktur sosial. Keanekaragaman adalah fakta yang tidak bisa dielakkan dalam kehidupan kolektif dan tidak bisa diharapkan eksistensinya atau tidak dapat ditekan tanpa tingkat kekerasan yang bisa diterima. Terlebih lagi sejak manusia terikat dan dibentuk oleh kebudayaan, penghormatan diri mereka secara erat terikat dengan penghormatan pada kebudayaannya. Penghormatan pada kebudayaan ini menumbuhkan rasa kesetiaan, memberi rasa percaya diri dan keberanian untuk berinteraksi dengan kebudayaan lain. Ada dua kelompok masyarakat beragama dalam masyarakat multikultural, yaitu masyarakat beragama "educated people" dan masyarakat beragama "ordiniary people". Kedua masyarakat beragama ini berbeda dalam memperlakukan agama yang mereka peluk. Bagi masyarakat beragama "educated people", memahami ajaran agama harus mengikutsertakan analisis rasional dan mengesampingkan pemahaman intuitif dan simbolik. Mereka mudah diajak bertoleransi terhadap agama dan pemeluk agama lain. Sebaliknya, masyarakat beragama "ordiniary people" memahami ajaran agama penuh dengan symbol-simbol dan tidak mempergunakan analisis rasional. Mereka mudah tersulut emosi dan sangat sulit bertoleransi dengan agama dan pemeluk agama lain. Kelompok ini mudah digerakkan oleh sekelompok orang atau komunitas baik yang beraliansi pada politik maupun pada sosial budaya. Toleransi beragama yang dilakukan dengan penuh kesadaran akan melahirkan sikap inklusif umat bergama. Sikap ini menganggap agama sendiri benar tetapi masih memberikan ruang untuk menyatakan kebenaran agama lain yang diyakini benar oleh umatnya. Sikap inklusif umat beragama akan mampu meruntuhkan sikap ekstrimis dan eksklusif umat beragama, yang biasanya melahirkan pemahaman fanatik buta dan radikalisme bahkan terorisme yang abadi terhadap umat berbeda agama. (Casram, 2016: 190)

Terlepas dari perbedaan teori, pandangan atau presepsi dalam menilai kejadian tersebut, namun semua sepakat minimal sementara ini bahwa gesekan, perseteruan atau konfik yang berbau agama atau sengaja dikaitkan agama, sangat mudah untuk diledakkan oleh pihak-pihak tertentu yang memiliki "hidden agenda". Belum lagi jika ditambahi "bumbu-bumbu" yang sengaja dilontarkan oleh orang yang lebih tepat disebut sebagai provokator dari pada pemerhati atau pengamat. Mereka bukannya berusaha untuk mendinginkan permasalahan atau memberikan solusi, tetapi mereka malah berusaha menjadi tokoh atau narasumber yang mencari kambing hitam. Orang yang memiliki sikap eksklusif (al-inghilaq), akan selalu mengakui kebenaran agamanya, bahkan hanya agamanya saja yang benar. Pandangan seperti ini tidak bisa begitu saja dikatakan salah, karena dorongan intrinsik agamanya yang melandasi pandangan seperti ini. Sikap inklusif (al-infitah) akan melahirkan sikap untuk menghormati dan menghargai keberadaan umat agama lain. Toleransi antar umat beragama secara benar merupakan salah satu pilar utama demi terwujudnya kerukunan antar umat beragama. (Hasan, 2013: 67) 
Ironis memang, karena agama di satu sisi mengajarkan dan mendambakan masyarakat yang religius penuh kedamaian, saling mencintai, saling mengasihi dan saling tolong menolong namun di sisi yang lain kondisi obyektif masyarakat jauh dari tatanan ideal agama. Agama laksana pedang bermata dua yang memiliki sisi tajam pada kedua sisinya. Di satu pihak mengajak manusia pada bentuk kehidupan yang harmonis, tetapi pada saat bersamaan mengakibatkan ketegangan dan bahkan kekerasan di antara para pengikutnya. Indonesia, secara tipikal merupakan masyarakat yang plural atau multicultural. Pluralitas masyarakat Indonesia tidak saja karena keanekaragaman suku, ras, dan bahasa, tetapi juga dalam agama. Dalam hubungannya dengan agama, pengalaman beberapa waktu terakhir memberikan kesan yang kuat akan mudahnya agama menjadi alat provokasi dalam menimbulkan ketegangan dan kekerasan baik intern maupun antar umat beragama. Ketegangan ini antara lain disebabkan karena:

(1) Umat beragama seringkali bersikap untuk memonopoli kebenaran ajaran agamanya, sementara agama lain diberi label tidak benar. Sikap seperti ini, dapat memicu umat agama lain untuk mengadakan perang suci atau jihad dalam rangka mempertahankan agamanya;

(2) Umat beragama seringkali bersikap konservatif, merasa benar sendiri (dogmatis) sehingga tak ada ruang untuk melakukan dialog yang kritis dan bersikap toleran terhadap agama lain.

Dua sikap keagamaan seperti itu membawa implikasi adanya keberagamaan yang tanpa peduli terhadap keberagamaan orang lain. Sikap ini juga akan menyebabkan keretakan hubungan antar umat beragama. Untuk melerai ketegangan yang terjadi di antara umat beragama, solusi yang dapat diambil untuk memecahkan permasalahan yaitu dengan mekanisme dialog keagamaan atau dikenal dengan istilah dialog antar iman. Dialog antar umat beragama ini diperkirakan mampu mengantarkan para pemeluk agama pada satu corak kehidupan yang inklusif dan terbuka, sehingga berpotensi untuk timbulnya jiwajiwa toleransi antar masyarakat. Dialog ini diharapkan akan membawa umat beragama pada konsep "unity in diversity" dan "to life together" dengan didasari oleh corak pemikiran yang pluralitas.

Toleransi merupakan salah satu kebajikan fundamental demokrasi, namun ia memiliki kekuatan ambivalen yang termanivestasi dalam dua bentuk, yaitu bentuk solid dan bentuk demokratis. Menjadi toleran adalah membiarkan atau membolehkan orang lain menjadi diri mereka sendiri, menghargai orang lain, dengan menghargai asal-usul dan latar belakang mereka. Toleransi mengundang dialog untuk mengkomunikasikan adanya bentuk pengakuan. Inilah gambaran toleransi dalam bentuknya yang solid (Craig: 2011).Toleransi berarti menjadi terbuka dan menerima keindahan perbedaan, sedangkan benih-benih toleransi adalah cinta yang dialiri oleh kasih sayang dan perhatian (Davis, 2010: 189-202). Toleransi juga merupakan menghargai individualitas dan perbedaan sambil 
menghilangkan topeng-topeng pemecah belah dan mengatasi ketegangan akibat kekacauan. Muynck, dkk: 2017).Toleransi merupakan salah satu diantara sekian ajaran inti dari Islam. Toleransi sejajar dengan ajaran fundamental yang lain, seperti kasih sayang (rahmah) kebijaksanaan (hikmah), kemaslahatan universal, dan keadilan. (Farrell, 2014: 650-662)

\section{BENTUK TOLERANSI DALAM BERAGAMA}

(Hornby, 1995: 67) Toleransi berasal dari bahasa latin yaitu "tolerantia", berarti kelonggaran, kelembutan hati, keringanan dan kesabaran. Secara umum istilah toleransi mengacu pada sikap terbuka, lapang dada, suka rela dan kelembutan. UNESCO mengartikan toleransi sebagai sikap saling menghormati, saling menerima, saling menghargai di tengah keragaman budaya, kebebasan berekspresi dan karakter manusia (Walzer, 1997: 56). Toleransi harus didukung oleh cakrawala pengetahuan yang luas, bersikap terbuka, dialog, kebebasan berpikir dan beragama. Pendek kata toleransi setara dengan sikap positif, dan menghargai orang lain dalam rangka menggunakan kebebasan asasi sebagai manusia.

Toleransi beragama adalah toleransi yang mencakup masalah-masalah keyakinan dalam diri manusia yang berhubungan dengan akidah atau ketuhanan yang diyakininya. Seseorang harus diberikan kebebasan untuk meyakini dan memeluk agama yang dipilihnya masing-masing serta memberikan penghormatan atas pelaksanaan ajaran-ajaran yang dianut atau diyakininya (Cassanova, 2008: 87).Toleransi beragama merupakan realisasi dari ekspresi pengalaman keagamaan dalam bentuk komunitas, (Wach, 1958: 121-132). Toleransi merupakan bentuk akomodasi dalam interaksi social, (Kinloch, 2005: 35).Umat beragama musti berupaya memunculkan toleransi untuk menjaga kestabilan sosial sehingga tidak terjadi benturan-benturan ideologi dan fisik di antara umat berbeda agama. Umat beragama seharusnya mampu untuk menghilangkan sikap fanatik radikal yang menyebabkan hilangnya sikap toleran dalam beragama.

Toleransi merupakan sikap yang positif. Indonesia sebagai negara yang berdasarkan Pancasila, memberi dan menjamin kebebasan bagi penduduknya untuk memeluk suatu agama dan kepercayaan yang disukainya tanpa ada paksaan. Hal ini telah dinyatakan dalam UUD 1945 pasal 29 ayat 2, bahwa:

"Negara menjamin kemerdekaan tiap-tiap penduduk untuk memeluk agama masingmasing dan untuk beribadat menurut agama dan kepercayaannya itu".

Toleransi agama merupakan sebuah keniscayaan untuk menjamin stabilitas sosial dari paksaan ideologis atau bahkan bentrokan fisik dalam masyarakat. Membangun masyarakat terdidik dan umat beragama yang berpikiran terbuka merupakan prasyarat untuk mencapai tujuan ini. Toleransi agama yang ideal mustinya dibangun melalui partisipasi aktif semua anggota masyakarat. 
Toleransi antar umat beragama dapat diwujudkan dalam bentuk antara lain:

a. Saling menghormati

b. Memberi kebebasan kepada pemeluk agama lain dalam menjalankan ibadah sesuai dengan agama dan kepercayaannya

c. Tolong-menolong dalam hidup bermasyarakat.

(Nisa dan Tualeka, 2016: 5) Meskipun demikian antar umat beragama dapat diwujudkan sikap sebagaimana di atas, akan tetapi bukan berarti dalam melaksanakan toleransi ini dengan mencampur adukkan antara kepentingan sosial dan akidah. Toleransi yang tidak menyangkut bidang akidah atau dogma masingmasing agama. Melainkan hanya menyangkut amal sosial antar sesama insan sosial dan sesama warga negara.

Toleransi beragama menurut Islam bukanlah untuk saling melebur dalam keyakinan. Bukan pula untuk saling bertukar keyakinan di antara kelompokkelompok agama yang berbeda itu. Toleransi di sini adalah dalam pengertian mu'amalah (interaksi sosial). Jadi, ada batas-batas bersama yang boleh dan tak boleh dilanggar. Inilah esensi toleransi di mana masing-masing pihak untuk mengendalikan diri dan menyediakan ruang untuk saling menghormati keunikannya masing-masing tanpa merasa terancam keyakinan maupun hakhaknya. Islam memiliki konsep yang jelas mengenai tidak adanya paksaan dalam beragama, "untukmu agamamu, dan untukku agamaku" adalah contoh populer dari toleransi dalam Islam atau dalam bahasa Arabnya yaitu "Lakum Dînukum Waliyadîn".

Munculnya kesadaran antar umat beragama yang diwujudkan dalam toleransi bisa menekan atau meminimalisasi bentrokan di antara mereka. Moto "Agree in Disagreement" yang diungkapkan oleh Mukti Ali untuk menciptakan rasa epoché dan toleransi antar umat beragama menjadi modal sosial yang kuat dalam toleransi beragama. Moto itu menyatakan toleransi beragama bukan hanya terjadi dalam kelompok beragama yang sama, tetapi juga dengan kelompok beragama yang berbeda. Toleransi beragama yang dikembangkan bukan hanya menghargai teologi dan iman masing-masing agama dan umat beragama, tetapi juga memahami dan menghargai budaya dari umat beragama tersebut. Toleransi beragama mampu memberikan dukungan bagi terbentuknya masyarakat madani yang diinspirasi oleh nilai-nilai supranatural.

Berkaitan dengan sikap toleran, seseorang hanya dituntut kesediaannya untuk menghargai dan menghormati pilihan orang lain terhadap sesuatu yang dianggapnya benar, tanpa mereduksi keyakinan dan pilihannya terhadap agamanya sendiri. Bukanlah toleransi lagi namanya jika seorang penganut agama dituntut bersikap dan berprilaku seperti penganut agama lain. Apalagi, bila hingga tahapan mengikuti dan mengamalkan ajaran agama lain demi toleransi. Dalam ranah toleransi, setiap penganut suatu agama harus tetap konsisten dengan agamanya 
sendiri dan diperlukan sikap untuk saling menghargai dan menghormati paham dan pandangan masing-masing. Toleransi harus ditanamkan dengan pengertian yang benar dan kesadaran yang penuh, bukan dengan pengelabuan, paksaan, dan intimidasi. Betapapun kita yakin akan kekeliruan dan kesalahan paham atau agama seseorang, tidak ada hak kita untuk membenci dan memarahinya. Tidak ada hak seseorang untuk menghukum orang lain atas kekeliruan paham dan kesalahan agamanya. Ada beberapa ketentuan yang harus dibekali seseorang agar mampu memahami agama orang lain, yaitu diantaranya:

(1) Perlengkapan yang sifatnya intelektual, yaitu yang diwujudkan dengan pencarian informasi sebanyak mungkin mengenai agama dan keyakinan orang lain.

(2) Adanya kondisi emosional yang cukup. Apa yang diperlukan adalah bukan sikap masa bodoh, tetapi adanya suatu keterikatan rasa, perhatian atau bahkan partisipasi.

(3) Adanya kemauan. Kemauan di sini harus ditujukan dan diarahkan kepada tujuan-tujuan yang konstruktif. (Wach, 1984: 15-18)

\section{KESIMPULAN}

Pemahaman mengenai kebebasan beragama di masyarakat pada hakikatnya belum sempurna. Toleransi yang seharusnya hadir dalam ruang lingkup beragama belum dilaksanakan secara maksimal. Sensitivitas yang terjadi berkaitan dengan agama selalu menjadi topik hangat dan bersifat emosional. Toleransi sebagai bentuk sikap yang positif hanya menuntut kesediaan seseorang untuk menghargai dan menghormati pilihan orang lain terhadap sesuatu yang dianggapnya benar (agama atau kepercayaan).

\section{DAFTAR PUSTAKA}

\section{Buku}

Adji, Oemar Seno. (1985). Peradilan Bebas Negara Hukum. Erlangga: Jakarta.

Al-Ashfahani, Al-Raghib. (2017). Al-Mufradat fi Gharib al-Quran. Dar al-Ma'rifat: Bairut.

Anshari, Endang Saifuddin. (1985). Ilmu, Filsafat, dan Agama, Penerbit PT. Bina Ilmu: Surabaya.

AS, Hornby. (1995). Oxford Advanced Learner'sDictionary. University Printing House: Oxford.

Asshiddiqie, Jimly. (2007). Pokok-pokok Hukum Tata Negara Indonesia Pasca Reformasi. Buana Ilmu Populer: Jakarta.

Cassanova, J. (2008). Public Religions In The Modern World. Chicago University Press: Chicago. 
Darajad, Zakiyah, dkk. (1996). Perbandingan Agama 2. Bumi Aksara: Jakarta.

Flood, Gavin. (2013). Beyond Phenomenology: Rethinking The Study of Religion. Bloomsbury Academic: London.

Harun Nasution. (1985). Islam Ditinjau dari Berbagai Aspeknya Jilid I. Penerbit UI Press: Jakarta.

Hatta, Mawardi. (1981). Beberapa Aspek Pembinaan Beragama dalam Konteks Pembangunan Nasional Di Indonesia. DEPAG RI: Jakarta.

Hidayat, Komaruddin dan Muhammad Wahyuni Nafis. (1995). Agama Masa Depan; Perspektif Filsafat Perennial. Penerbit Paramadina: Jakarta.

Kinloch, Graham C. (2005). Sociological Theory: Development and Major Paradigm. Pustaka Setia: Bandung.

Moran, Dormort. (2012). Introduction To Phenomenology. New York.

Nasution, Harun. (1985). Islam Ditinjau dari Berbagai Aspeknya. Penerbit UI Press: Jakarta.

Permana, Ahmad Norma. (2000). Metodologi Studi Agama. Penerbit Pustaka Pelajar: Yogyakarta.

Rasjidi. (1990). Empat Kuliah Agama Islam di Perguruan Tinggi. Penerbit PT. Bulan Bintang: Jakarta.

Smith, Rhona K. M., dkk. (2008). Hukum HAM. PUSHAM UII: Yogyakarta.

Suripto, BA, dkk. (1993). Tanya Jawab Cerdas Tangkas P4 Undang-undang Dasar 1945 dan GBHN 1993. Pustaka Almas: Jakarta.

Wach, Joachim. (1984). Ilmu Perbandingan Agama. Rajawali Press: Jakarta.

Wach, Joachim. (1958). The Comparative Study of Religion. Colombia University Press: New York.

Walzer, Michael. (1997). On Toleration Castle Lectures in Ethics, Politics, and Economics. Yale University Press: New York.

\section{Artikel Jurnal}

Abu Hafsin. (2010). Pemikiran Demokrasi di Indonesia antara Pembatasan dan Kebebasan Beragama, Jurnal Analisa 17(1): 10.

Anita Khusnun Nisa dan M. Wahid Nur Tualeka. (2016). "Kajian Kritis tentang Toleransi Beragama dalam Islam", Al-Hikmah: Jumal Studi Agama-agama 2(2): 5 .

Casram. (2016). Membangun Sikap Toleransi Beragama dalam Masyarakat Plural, Wawasan, Jurnal Ilmiah Agama dan Sosial Budaya 1(2): 190.

Craig, C. J. (2011). Narrative inquiry in teaching and teacher education. Narrative Inquiries into Curriculum Making in Teacher Education (Vol. 13). Emerald.

Davis, A. (2010). Defending religious pluralism for religious education. Ethics and Education 5(3): 189-202. 
De Muynck, B., Vos, P., Hoogland, J., \& Van der Stoep, J. (2017). A Distinctive of Christian Higher Education: Educating for Vocation. Christian Higher Education 16(1-2): 3- 10.

Farrell, F. (2014). A critical investigation of the relationship between masculinity, social justice, religious education and the neo-liberal discourse. Education + Training 56(7): 650-662.

Fatmawati. (2011). Perlindungan Hak atas Kebebasan Beragama dan Beribadah dalam Negara Hukum Indonesia. Jurnal Konstitusi 8(4): 499.

Frans Sayogie. (2013). Perlindungan Negara terhadap Hak Kebebasan Beragama: Perspektif Islam dan Hak Asasi Manusia Universal, Jurnal Hukum PRIORIS 3(3): 43.

Michael J. Johanis. (2014) Perlindungan Kebebasan Beragama dalam Menjalankan Ibadahnya menurut Perspektif Hak Asasi Manusia, Lex et Societatis 2(1): 7.

Moh Abdul Kholiq Hasan. (2013). Merajut Kerukunan dalam Keragaman Agama di Indonesia, Jurnal Studi Islam 14(1): 67.

Sodikin. (2013). Hukum dan Kebebasan Beragama, Jurnal Cita Hukum 1(2): 177.

Yusdani. (2011). Kebebasan Beragama dalam perspektif Hak Asasi Manusia, Jurnal AlMawarid 11(2): 268-269.

\section{Skripsi/Disertasi}

Muhammad Tahir Azhary, Negara Hukum: Suatu Studi tentang Prinsip Prinsipnya Dilihat dari Segi Hukum Islam, Implementasinya, $\mathrm{p}$ ada Periode Negara Madinah dan Masa Kini, (Jakarta: Bulan Bintang, 1992), hal. 74. Buku ini berasal dari disertasi beliau yang dipertahankan di hadapan Sidang terbuka Senat Guru Besar Universitas Indonesia, 19 Maret 1991.

Siti Khurotin, Skripsi Pelaksanaan Pendidikan Agama Berwawasan Multikultural dalam membina toleransi Beragama Siswa di SMA "Selamat Pagi Indonesia" Batu, (Malang: Fakultas Tarbiyah Universitas Islam Negeri Maulana Malik Ibrahim, 2010) hlm. 43

Makalah

Soetandyo Wignjosoebroto, Hak Menentukan Nasib Sendiri dan HAM, Makalah Diskusi Panel PSPMAA \& NNB UNPAD \& Balitbang DEPLU RI, 10 Agustus 1996. 